\title{
The Eastern Asian Research on Gender Bias in Secondary School Textbooks
}

\author{
Chia Lin Lu \\ English Teacher, Municipal Gong-Guan Junior High School \\ E-mail: fortunalu@gmail.com
}

Yao Jung Lin (Corresponding author)

$\mathrm{Ph} \mathrm{D}$, Graduate Institute of Education, National Changhua University of Education

E-mail: a8413003@gmail.com

Received: August 23, 2014 Accepted: September 2, 2014 Published: September 2, 2014

doi:10.5296/ijele.v2i2.6260 URL: http://dx.doi.org/10.5296/ijele.v2i2.6260

\begin{abstract}
Students might take much time to learn from textbooks to develop their gender roles at school, the proper textbooks which attained the objectives of gender equality were needed. To take the cultural context into consideration, the EFL studies on gender bias in textbooks (GBIT) of secondary schools in the regions of eastern Asia, including China, Japan, Korea, and Taiwan, were chosen to reviewed and discussed in this article. This review might contribute to understand the development of research on GBIT in eastern Asia. Those reseach on GBIT not only helped the positive development of gender equity pertaining to textbooks but also informed secondary school teachers and students of the need to take heed of those gender-biased contents in textbooks.
\end{abstract}

Keywords: gender bias, textbook, secondary school 


\section{Introduction}

The Education for All movement, an international initiative launched first in 1990, promoted gender equity in primary and secondary education worldwide (UNESCO, 2012). Its goals were to eliminate gender disparities by 2005 and to put gender equity into practice in campus by 2015 . To be specific, it was expected that the number of girls enrolled in primary and secondary schools could be equal to that of boys all around the world. Those girls would then be educated as equally as boys. As Irina Bokova (2012) indicated, gender equality had been one of essential elements of universal human rights and fundamental freedoms. The research on gender representation had also been conducted worldwide and paid much attention continuously (Blumberg, 2008). However, even though gender equity in secondary education had been a general upward trend globally, about two-thirds countries in the world still remained gender unfair at present (Fiske, 2012). It thus needed many efforts to attain the goal of educational gender equality worldwide.

Because students would spend most of their time on textbook learning to develop their identities of gender at school (Evans \& Davies, 2000; Taylor, 2003), the proper textbooks related to gender equality education were needed. A good number of studies on gender bias in textbooks (GBIT) had been done worldwide (Blumberg, 2008), most of which adopted those aforementioned criteria to conduct content analysis of the texts or pictures. In order to take the cultural context into consideration, the EFL studies on GBIT of secondary school in the regions of eastern Asia were chosen to reviewed in order to understand the development of research on it. The research from China (Chen, 2008; Tung, 2011; Zhao, 2003; Zhu, 2011), Japan (Otlowski, 2003; Sano, Iida, \& Hardy, 2001), Korea (Kim, 2012), and Taiwan (Huang, 2009; Su, 2008; Tang, 2013; Wu, 2002a, 2002b; Yang, 2005), were reviewed and dicussed below.

\section{Those Research on Gender Bias}

\subsection{China}

China had had some EFL research on GBIT since 2000, including four ones regarding secondary school textbooks. In 2000, the Ford Foundation funded 20 researchers to do studies on GBIT (Blumberg, 2008), and one research was about secondary school (Zhao, 2003). Their overall common research findings were that the curricular appeared gender-biased and could not conform to the real life experience of gender in new changing China's society (Ross \& Shi, 2003). About the secondary school research, Zhao (2003) briefly indicated that the conflicting viewpoints with regard to gender roles were found in the analysis of texts. That is, although female characters seemed to be appeared equally as male ones in the activities, girls still performed better in housework than boys did as traditionally expected.

Besides, Chen (2008) conducted studies on secondary school textbook series, Oxford. The pictures and texts of the six books were analyzed and gender bias was found in the content analysis. In the analysis of pictures, males owned more chances to be successful people than female did because the ratio of male mentioned to female mentioned in the pictures was 20:7. Furthermore, female were often portrayed so weak that they needed to ask for help from males. For instance, boy students might guide girls to solve academic problems when the 
latter felt confused about them or uttered the words "I don't know" or "I don't understand." On the other hand, in the analysis of texts, male characters also performed better than female characters. For example, male characters would be depicted as top students or the winners of football games and writing competitions. On the contrary, female characters suffered from problems and needed to seek for males' help even when females were viewed as excellent students. It was obvious that girls often appeared timid or imcompotent as they could be scared to death on hearing the strange noise in the bush or got sick when shopping in the mall and had to be sent to hospital by policemen.

Another version of textbook series, Jen-Ai, composed of six books, was explored by Zhu (2011). The visibility, gender role, and firstness within pictures and texts were analyzed. For visibility, male characters appeared more than female characters in most of the pictures, especially those related to the issues of sports, science, politics, and adventure. These male characters could have more chances to become outstanding successful persons than female characters. Those professional occupations like inventors or doctors were also assigned to male characters more than female ones. As to gender roles, characters were depicted as traditionally stereotypical. Females would have to look after children and do housework as mothers while working outside were the duty of males. Males' jobs thus outnumbered females' ones. Moreover, the males' precedent orders of gender mentions were apparent in the texts, such as he/she, his/her, boy/girl, man/woman, father/mother, and Mr./Mrs. Only the diction for introduction "ladies and gentlemen" was an exception. Hence, Zhu's research might reflect the male-dominated gender bias in Jen-Ai.

The latest research on GBIT for secondary school was undertaken by Tung (2011). It was a simple study on Jen-Chiao series. The characters and language of its $4^{\text {th }}, 5^{\text {th }}$, and $6^{\text {th }}$ books were analyzed. In the analysis of characters, male characters were portrayed more as main characters or outstanding people than female characters. The ratio of main characters for males to those for females was 1: 0.61 , and, similarly, the ratio of outstanding people for males to those for females was 1: 0.3. In the analysis of English language, the male referent permeated through the three books because "man" or "he" referred to both men and women. Females usually lost the chances to own their own identities in the representation of language. From the analysis of the characters and language above, the gender-biased perspective were found in the texts.

The four studies mentioned above indicates that those EFL textbooks utilized in Chinese secondary schools presented gender-biased viewpoints concerning gender visibility, stereotypical depiction of gender role, and language. China still had a long way to go to eliminate gender bias in teaching materials (Blumberg, 2008) even if China government had devoted to the implementation of educational policies of gender equity.

\subsection{Japan}

There were only two EFL studies published in English on GBIT of secondary school in Japan in recent past. The first research was undertaken by Sano, Iida, \& Hardy (2001). They explored the language of five series of secondary school textbooks, including New Horizon English Course, New Crown English Series, Sunshine English Course, Total English, and One World English Course. Their analysis included gender-imbalanced diction, gender influence on verb use or choice of verbs, and chapter topics. In their research findings, there 
was no significant gender imbalance in the diction like chairman; nevertheless, female characters acted and spoke in the text more because the number of female utterances exceeded that of male ones. Furthermore, male characters appeared prominent because they were given more chances to be main characters, and they often use the powerful verbs like "choose" or "decide" more than female characters in the texts. The similar trend was also found in the analysis of chapter topics due to its outnumbering of male-oriented chapter topics which featured male stories and examples. Therefore, these analyses of language and topics represented more male dominance than female ones.

In the other Japanese study, Otlowski (2003) examined gender bias in the EEL textbook series, Expressway A. The occupational jobs and the use of language were analyzed. Male characters were portrayed more at work in the pictures than female characters as the ratio of the two was 1: 0.42 . Female characters had fewer chances to work outside as their male counterpart. They could not get rid of the stereotypical domestic roles like mothers, who did housework and went shopping more often than not. As for the part of language analysis, the distinctive uses of "Ms." and "Mrs." were found inappropriate due to its deliberate differentiation between married and unmarried women. Owing to the differentiation not currently used in the US or the UK, it appeared gender-biased in its language use in the text. This study obviously showed the existence of male preference in the representation of occupation and language, and his research findings were partly similar to Sano, Iida, \& Hardy's (2001) despite their different criteria for GBIT.

\subsection{Korea}

In Korea, only one EFL study written in English on GBIT with regard to secondary school was found. It was Kim's (2012) paper, which probed into gender bias in the three textbooks series used in Korea, including Doosan Dong-A, Chunjae Education, and Neungyule Education. The occupation and activities in the pictures of those textbooks were analyzed. In the part of occupation, the jobs appeared the most was "teacher" (88\%) for males, and, "housewife" ( $88 \%)$ for females. The finding of many male's jobs as teachers conformed to the stereotypical images of male dominant roles as teachers in Korea's traditional culture. On the other hand, female characters portrayed as housewives also matched the traditional Korean female roles as mothers or wives who did house chores and looked after children at home. Furthermore, other jobs attributed to males more were "doctors" $(\mathrm{n}=5)$ and "scientists" $(n=3)$. These two jobs were representative of higher social classes to a certain extent than the job "clerks" $(n=6)$ attributed to females the most.

In addition, as to the analysis of activities, males (67\%) were represented more in the activities of playing sports than females (33\%). It was significant that the sports for male characters were often represented as team sports like soccer, basketball, and baseball, while most of sports for female characters were those for a single person, such as running or jogging. Another activity for males more was "computing" $(n=7)$, so working on computers could be thought of as males' activities instead of female's ones. The use of a computer might show one's technical capability, and thus males could possess it to perform better than females implicitly. On the other hand, female characters were portrayed as ones who went shopping $(n=4)$ and talked on phones $(n=8)$ more often than male characters. The stereotypical images of mothers who were busy at house chores and appeared talkative at 
home were presented from these two portraits of activities. It was obvious that the analysis of the occupation and activities in these textbooks reflected gender imbalance between the portraits of males and those of females.

On the whole, most of these Eastern Asian research findings represented gender bias in those EFL textbooks. The stereotypical image of mothers became the common one for those textbook series (Kim, 2012; Otlowski, 2003; Zhao, 2003; Zhu, 2011). This finding might indicate the importance of the role of mothers for Eastern Asian countries. However, there were some differences in their findings. Different from the textbooks of the other two countries, Chinese textbooks tended to emphasize male dominance in contribution and capability (Chen, 2008; Tung, 2011; Zhu, 2011). This tendency might implicitly give females the image of weakness in contrast to males. Moreover, the two Japanese studies (Otlowski, 2003; Sano, et al., 2001) were inclined to conduct investigations on language pertaining to gender bias, little of which was found in those Chinese or Korean studies. This inclination probably was related to the researchers' individual preferences or to the borrowing of English language in the Japanese diction like homerun or aluminum than that of the other two countries.

\subsection{Taiwan}

There had been five studies on GBIT for secondary school since 2000 in Taiwan. Those research before 2005 analyzed the official textbook published by National Institute for Compilation and Translation (NICT), and later the current textbook series, such as Kangshan, Nani, and Hanlin, were chosen to be research objects to analyze their GBIT.

First of all, $\mathrm{Wu}$ (2002a, 2002b) had adopted Fang's (2000) criteria mentioned earlier to examine the pictures and texts in the third and fourth books of NICT. Her analysis showed both the equal and stereotypical representations of females and males. In the part of equal representation, female characters were given diverse kinds of occupational jobs which needed professional trainings like doctors. The activities traditionally undertaken by males were observed done by females, such as playing ball or using computer. Both of females and males might conduct activities together like housework doing. On the contrary, in the part of stereotypical representation, females were still represented stereotypically in some depictions of gender roles. Female characters played more roles of caretakers than male characters as women were portrayed to be suitable to serve the works of looking after children. It was the stereotypical image of mothers who took care of children when children were sick in bed and who went shopping in the market with boys and girls lest they could not be taken care of well. Furthermore, female characters were even described to have the debased personality traits of weakness. They needed to be protected by strong males, and in order to ingratiate themselves with males, females also had to keep fit and care about males' preferences.

In Yang's (2005) study, the text analysis of NICT's six books tended to represent gender bias. The titles, visibility, and language were examined respectively. First, the title of these lessons reflected stereotypical male dominance. Boys were portrayed to be good at sport while girls appeared less interested in or even incompetent at it. In other words, outdoor activities like sport belonged to males rather than females, whose gender activities were thus restricted in these depictions. Apart from titles, the low visibility of female characters in the pictures was apparent in the analysis. Men and boys appeared two times more than women and girls, who 
in actuality were deprived of the equal portraits in the lessons. Moreover, the language analysis indicated that the biased marital status of females still existed. The courtesy titles of "Mrs." and "Miss" appeared 37 times in total in those textbooks, which repeatedly reminded readers whether the woman was married or unmarried. Obviously, these continual uses of courtesy titles might negatively represent females, but, in contrast, males were not treated like this.

Su's (2008) study focused upon the exploration of gender ideology embedded within textbooks. The visibility and stereotyping were probe into in those textbooks series, Kangshan, Nani, and Hanlin. First, the gender proportions in occupational jobs were found imbalanced. Male characters still owned higher visibility than female characters in those descriptions of occupation. Besides, there were also gender stereotypes in the portraits of appearance and personality. Males were apparently depicted as strong and intelligent while females stereotypically appeared beautiful in order to attract males' attentions.

The fourth Taiwan's study was Huang's (2009), which examined the representation of gender roles in pictures and texts of Kangshen, Nani, Hanlin, and Hersheng. Her study indicated that gender stereotyping still existed in them. In the pictures, the distribution of male and female characters turned out to be unequal. Male characters were depicted more than female characters in the frequencies of visibility. In addition, her analysis of occupational jobs for gender also appeared imbalanced. Male characters occupied more kinds of jobs than female characters, some of which even were referred to as prestigious. On the other hand, the traditional restricted roles like housekeepers or kid caretakers still belonged to female characters, whose occupational roles assigned kept gender-biased. The similar situations occurred in the distribution of activities. As a whole, the various activities were attributed to male characters more than female characters, and the indoor activities pertaining to cooking and housework doing were attributed to female characters. In contrast to female's indoor activities, male characters' owned more outdoor activities. Furthermore, the language use in the text analysis appeared partly stereotypical and partly gender-balanced. The stereotypical gender-biased representation consisted in the use of courtesy titles like "Mrs." and "Miss" and in the male terms like "fisherman" or "mailman." On the contrary, the neutral terms for males and females like "they" were frequently mentioned in the text instead of the use of generic "he" or "his," a language pratcive that appeared gender-balanced.

The latest study found was conducted by Tang (2013), who explored the sexist language and stereotypical activities in the series, Kangshen, Nani, and Hanlin. There were two types found gender-biased. In the type of sexist language, the suffix, man, was widespread used in the texts. In the type of stereotyping, male characters were depicted as active and vigorous in the instrumental independent activities, and female characters, obedient and placid in passive dependent activities according to Kortenhaus \& Demarest's (1993) forms of stereotypical gender activities.

Most of these local research revealed gender bias in their analyses, which male preferences permeated with the texts and illustration, whether in the old series, NICT, or those new series, Kangshen, Nani, and Hanlin. In the analysis of NICT, Wu's and Yang's research focused upon different criteria in their examinations of GBIT respectively. However, on the whole, the gender role, titles, visibility, and language were regarded as stereotypical for the biased 
portraits of female characters in their findings. On the other hand, the depictions of occupation and activities positively offered female characters as equal chances as male ones. These results showed that gender equity had not presented thoroughly in any aspects in the official NICT. In addition, in the analyses of those current new series, Kangshen, Nani, Hanlin, and Hersheng, the masculine dominance embedded in the representations of various types of gender bias was found, including visibility, stereotyping, and language. Male characters would appear more in the textual and visual representations, be paid more attention in the portraits of occupation and activities, and enjoy the traditional privileges of language by the implicit suppression of females.

The studies mentioned above would be summarized in Table 1 and Table 2 below. Table 1 was the analysis of illustration, and Table 2, that of text. The former consisted of two types, visibility and stereotyping, and the latter was added to two more types, focus and language.

Table 1. The research on GBIT in the illustration

\begin{tabular}{|c|c|c|c|c|}
\hline Type & Criteria & Region & Author & Result \\
\hline \multirow[t]{2}{*}{ Visibility } & $\begin{array}{l}\text { Frequency } \\
\text { appearance }\end{array}$ & China & Zhu (2011) & $\begin{array}{l}\text { Male characters appeared } \\
\text { more than female characters. }\end{array}$ \\
\hline & & Taiwan & $\begin{array}{l}\text { Huang } \\
(2009)\end{array}$ & $\begin{array}{l}\text { There were more male } \\
\text { illustrations. }\end{array}$ \\
\hline \multirow[t]{5}{*}{ Stereotyping } & Contribution & China & $\begin{array}{l}\text { Chen } \\
(2008)\end{array}$ & $\begin{array}{l}\text { Males occupied more } \\
\text { chances to be successful } \\
\text { people than females. }\end{array}$ \\
\hline & Portrayal & China & $\begin{array}{l}\text { Chen } \\
(2008)\end{array}$ & $\begin{array}{l}\text { Female were portrayed as the } \\
\text { weak. }\end{array}$ \\
\hline & $\begin{array}{l}\text { Occupational } \\
\text { job }\end{array}$ & Japan & $\begin{array}{l}\text { Otlowski } \\
(2003)\end{array}$ & $\begin{array}{l}\text { Male characters were } \\
\text { portrayed more at work than } \\
\text { female characters. }\end{array}$ \\
\hline & & Korea & Kim (2012) & $\begin{array}{l}\text { The jobs appeared } \\
\text { stereotypical, such as } \\
\text { "teacher" ( } 88 \%) \text { for males, } \\
\text { and "housewife" ( } 88 \%) \text { for } \\
\text { females. }\end{array}$ \\
\hline & Activities & Korea & Kim (2012) & $\begin{array}{l}\text { Males were represented } \\
\text { specifically more in the } \\
\text { activities of playing sports } \\
(67 \%) \text { than females. }\end{array}$ \\
\hline
\end{tabular}


Table 2. The research on GBIT in the text

\begin{tabular}{|c|c|c|c|c|}
\hline Type & Criteria & Region & Author & Result \\
\hline \multirow[t]{3}{*}{ Visibility } & \multirow[t]{3}{*}{$\begin{array}{l}\text { Frequency of } \\
\text { appearance }\end{array}$} & Taiwan & $\begin{array}{l}\text { Yang } \\
(2005)\end{array}$ & $\begin{array}{l}\text { Females appeared less than } \\
\text { males. }\end{array}$ \\
\hline & & Taiwan & $\mathrm{Su}(2008)$ & $\begin{array}{l}\text { The gender proportions in } \\
\text { occupational jobs were } \\
\text { found imbalanced. }\end{array}$ \\
\hline & & Taiwan & $\begin{array}{l}\text { Huang } \\
(2009)\end{array}$ & $\begin{array}{l}\text { Male characters were } \\
\text { depicted more than female } \\
\text { characters. }\end{array}$ \\
\hline \multirow[t]{2}{*}{ Focus } & \multirow[t]{2}{*}{ Main character } & China & $\begin{array}{l}\text { Tung } \\
(2011)\end{array}$ & $\begin{array}{l}\text { Male characters were } \\
\text { portrayed more as main } \\
\text { characters. }\end{array}$ \\
\hline & & Japan & $\begin{array}{l}\text { Sano, } \\
\text { Iida, \& } \\
\text { Hardy } \\
(2001)\end{array}$ & $\begin{array}{l}\text { Male characters appeared } \\
\text { prominent when given } \\
\text { more chances to be main } \\
\text { characters. }\end{array}$ \\
\hline \multirow[t]{7}{*}{ Stereotyping } & \multirow[t]{4}{*}{ Portrayal } & China & $\begin{array}{l}\text { Chen } \\
(2008)\end{array}$ & $\begin{array}{l}\text { 1. Male characters } \\
\text { performed better than } \\
\text { female characters. }\end{array}$ \\
\hline & & & & $\begin{array}{l}\text { 2. Female characters } \\
\text { appeared timid and felt } \\
\text { impotent. }\end{array}$ \\
\hline & & Taiwan & $\begin{array}{l}\mathrm{Wu} \\
(2002 \mathrm{a}, \\
2002 \mathrm{~b})\end{array}$ & $\begin{array}{l}\text { Female had the biased } \\
\text { personality trait of } \\
\text { weakness. }\end{array}$ \\
\hline & & Taiwan & $\mathrm{Su}(2008)$ & $\begin{array}{l}\text { There were gender } \\
\text { stereotypes in the portraits } \\
\text { of appearance and } \\
\text { personality }\end{array}$ \\
\hline & \multirow[t]{2}{*}{ Contribution } & China & $\begin{array}{l}\text { Zhu } \\
(2011)\end{array}$ & $\begin{array}{l}\text { Male characters had more } \\
\text { chances to become } \\
\text { outstanding } \\
\text { people. }\end{array}$ \\
\hline & & China & $\begin{array}{l}\text { Tung } \\
(2011)\end{array}$ & $\begin{array}{lr}\text { Male characters } & \text { were } \\
\text { portrayed more } & \text { as } \\
\text { outstanding people. } & \\
\end{array}$ \\
\hline & Occupation & China & $\begin{array}{l}\text { Zhu } \\
(2011)\end{array}$ & $\begin{array}{l}\text { The professional } \\
\text { occupations like inventors } \\
\text { or doctors were assigned to } \\
\text { male characters more. }\end{array}$ \\
\hline
\end{tabular}




\begin{tabular}{lll} 
China & $\begin{array}{l}\text { Tung } \\
(2011)\end{array}$ & $\begin{array}{l}\text { Females' occupation were } \\
\text { highlighted, such as } \\
\text { policewomen, women } \\
\text { doctors, actresses, and } \\
\text { waitresses. }\end{array}$ \\
\hline Taiwan & Wu & $\begin{array}{l}\text { Female characters were } \\
\text { given diverse kinds of } \\
\text { occupational jobs, which } \\
\text { needed professional } \\
\text { training like doctors. }\end{array}$ \\
\hline
\end{tabular}

\begin{tabular}{ll}
\hline Taiwan $\quad \mathrm{Su}(2008)$ & $\begin{array}{l}\text { The gender proportion in } \\
\text { occupational jobs was } \\
\text { found imbalanced. }\end{array}$ \\
\hline
\end{tabular}

Taiwan Huang Male characters occupied

(2009) more kinds of jobs than female characters.

\begin{tabular}{|c|c|c|c|}
\hline \multirow[t]{3}{*}{ Domestic role } & China & $\begin{array}{l}\text { Zhu } \\
(2011)\end{array}$ & $\begin{array}{lcr}\text { Females looked } & \text { after } \\
\text { children } & \text { and } & \text { did } \\
\text { housework. } & & \\
\end{array}$ \\
\hline & Taiwan & $\begin{array}{l}\mathrm{Wu} \\
(2002 \mathrm{a}, \\
2002 \mathrm{~b})\end{array}$ & $\begin{array}{l}\text { Females were represented } \\
\text { stereotypical as the roles of } \\
\text { caretakers. }\end{array}$ \\
\hline & Taiwan & $\begin{array}{l}\text { Yang } \\
(2005)\end{array}$ & $\begin{array}{l}\text { Males occupied most of } \\
\text { characters as traditional } \\
\text { basketball players or } \\
\text { husbands. }\end{array}$ \\
\hline \multirow[t]{4}{*}{ Activities } & China & $\begin{array}{l}\text { Zhao } \\
(2003)\end{array}$ & $\begin{array}{l}\text { Girls performed better at } \\
\text { home than boys. }\end{array}$ \\
\hline & Taiwan & $\begin{array}{l}\mathrm{Wu} \\
(2002 \mathrm{a}, \\
2002 \mathrm{~b})\end{array}$ & $\begin{array}{l}\text { The activities traditionally } \\
\text { undertaken by males were } \\
\text { observed done by females, } \\
\text { such as playing ball or } \\
\text { using computer. }\end{array}$ \\
\hline & Taiwan & $\begin{array}{l}\text { Huang } \\
(2009)\end{array}$ & $\begin{array}{l}\text { The various activities were } \\
\text { attributed to male } \\
\text { characters more than } \\
\text { female characters. }\end{array}$ \\
\hline & Taiwan & $\begin{array}{l}\text { Tang } \\
(2013)\end{array}$ & $\begin{array}{l}\text { Male characters were } \\
\text { depicted as active and } \\
\text { vigorous, and, female } \\
\text { characters, as obedient and } \\
\text { placid. }\end{array}$ \\
\hline male referent & China & Tung & "Man" or "he" \\
\hline
\end{tabular}


(2011) referred to both men and women.

\begin{tabular}{|c|c|c|c|}
\hline & Taiwan & $\begin{array}{l}\text { Huang } \\
(2009)\end{array}$ & $\begin{array}{l}\text { The neutral terms for } \\
\text { males and females like } \\
\text { "they" were often used. }\end{array}$ \\
\hline \multirow[t]{3}{*}{ suffix } & Japan & $\begin{array}{l}\text { Sano, } \\
\text { Iida, \& } \\
\text { Hardy } \\
(2001)\end{array}$ & $\begin{array}{l}\text { There was no } \\
\text { gender-imbalanced diction } \\
\text { like chairman. }\end{array}$ \\
\hline & Taiwan & $\begin{array}{l}\text { Huang } \\
(2009)\end{array}$ & $\begin{array}{l}\text { There were male terms like } \\
\text { "fisherman" or "mailman." }\end{array}$ \\
\hline & Taiwan & $\begin{array}{l}\text { Tang } \\
(2013)\end{array}$ & $\begin{array}{l}\text { The suffix, -man, was } \\
\text { frequently used. }\end{array}$ \\
\hline \multirow[t]{3}{*}{$\begin{array}{c}\text { the uses of "Ms." and } \\
\text { "Mrs." }\end{array}$} & Japan & $\begin{array}{l}\text { Otlowski } \\
(2003)\end{array}$ & $\begin{array}{l}\text { The distinctive uses of } \\
\text { "Ms." and "Mrs." Were } \\
\text { thought of } \\
\text { inappropriate. }\end{array}$ \\
\hline & Taiwan & $\begin{array}{l}\text { Yang } \\
(2005)\end{array}$ & $\begin{array}{l}\text { The courtesy titles of } \\
\text { "Mrs.," "Miss," and } \\
\text { "Miss" were used. }\end{array}$ \\
\hline & Taiwan & $\begin{array}{l}\text { Huang } \\
(2009)\end{array}$ & $\begin{array}{l}\text { The courtesy titles like } \\
\text { "Mrs." and "Miss" were } \\
\text { used. }\end{array}$ \\
\hline Firstness & China & $\begin{array}{l}\text { Zhu } \\
(2011)\end{array}$ & $\begin{array}{l}\text { The males' precedent } \\
\text { orders of gender mentions } \\
\text { appeared often. }\end{array}$ \\
\hline
\end{tabular}

\section{Conclusion}

The exploration of gender representations in textbooks in this article would represent the concerns of researchers in the four countries for gender representation in the textbooks. Their reseach not only helped the positive development of gender equity pertaining to textbooks but also informed secondary school teachers and students of the need to take heed of those gender-biased contents in textbooks. More importantly, the authors or editors of textbooks should examine and revise those contents involved in gender bias based upon the suggestions of those research findings. In consequently, students would be likely to be free from misleading gender-biased textbooks as they learnt from them at school.

\section{References}

Blumberg, R. L. (2008). The invisible obstacle to educational equality: Gender bias in textbooks. Prospects, 38(3), 345-361. http://dx.doi.org/10.1007/s11125-009-9086-1

Bokova, I. (2012). Foreword. In E. B. Fiske (Ed.), World atlas of gender equality in education (p. 1). Paris: UNESCO. 
Chen, P. (2008). English teacher should notice gender bias in textbook. The Science Education Article Collects, 23, 128-130.

Evans, L., \& Davies, K. (2000). No sissy boys here: A content analysis of the representation of masculinity in elementary school reading textbooks. Sex Roles, 42(3), 255-270. http://dx.doi.org/10.1023/A:1007043323906

Fiske, E. B. (2012). World atlas of gender equality in education. Paris: UNESCO.

Huang, C. H. (2009). Gender roles in junior high school English textbooks. Unpublished master's thesis, National Chung Cheng University, Chiayi County.

Kim, H. (2012). Social and cultural issues in some EFL textbooks in Korea. Hawaii Pacific University TESOL Working Paper series, 10, 30-39.

Kortenhaus, C., \& Demarest, J. (1993). Gender role stereotyping in children's literature: An update. Sex Roles, 28(3), 219-232. http://dx.doi.org/10.1007/BF00299282

Otlowski, M. (2003). Ethnic diversity and gender bias in EFL textbooks. Asian EFL Journal, $5(2)$.

Ross, H., \& Shi, J. (2003). Entering the gendered world of teaching materials, Part II. Chinese Education and Society, 36(3), 3-9. http://dx.doi.org/10.2753/CED1061-193236033

Sano, F., Iida, M., \& Hardy, T. (2001). Gender representation in Japanese EFL textbooks. Paper presented at the PAC3 at JALT, Kitakyushu, JAPAN.

Su, Y. T. (2008). A study of the gender ideology of English textbooks in junior high school. Unpublished master's thesis, National Changhua University of Education, Changhua County.

Tang, S. C. (2013). Gender equality in English textbooks and teacher awareness of gender bias in junior high school EFL education. Unpublished master's thesis, Tamkang Univerity, New Taipei.

Taylor, F. (2003). Content analysis and gender stereotypes in children's books. Teaching Sociology, 31(3), 300-311. http://dx.doi.org/10.2307/3211327

Tung, H. N. (2011). The study on gender bias in junior high school English textbooks. Jiannan Literature, 328, 156.

UNESCO. (2012). Education for all goals. Retrieved Oct 10, 2012, from http://www.unesco.org/new/en/education/themes/leading-the-international-agenda/educationfor-all/the-efa-movement/

$\mathrm{Wu}, \mathrm{Y}$. L. (2002a). Examining junior high school textbooks to see whether they conform to the principles of gender equity. Education of Gender Equity Quarterly, 18, 92-100.

$\mathrm{Wu}, \mathrm{Y}$. L. (2002b). Examining the gender ideology in English textbooks of the second year of junior high school. Curriculum \& Instruction Quarterly, 5(3), 81-98.

Yang, M. T. (2005). A study of gender roles in the English textbooks of junior high schools. 
Unpublished master's thesis, National Chung Cheng University, Chiayi County.

Zhao, P. (2003). Mother and I: An analysis of the gender roles of two generations of females in junior middle school English-language teaching materials. Chinese Education and Society, 36(3), 19-26.

Zhu, C. Q. (2011). Research on the sex roles in project English. Journal of Fujian Institute of Education, 1, 83-86.

\section{Copyright Disclaimer}

Copyright for this article is retained by the author(s), with first publication rights granted to the journal.

This is an open-access article distributed under the terms and conditions of the Creative Commons Attribution license (http://creativecommons.org/licenses/by/3.0/). 